\title{
Risk of exposure to airborne Ambrosia pollen from local and distant sources in Europe - an example from Denmark
}

\author{
Janne Sommer ${ }^{1}$, Matt Smith ${ }^{2,3,4}$, Branko Šikoparija ${ }^{5}$, Idalia Kasprzyk ${ }^{6}$, Dorota Myszkowska7, \\ Łukasz Grewling ${ }^{3}$, Carsten A. Skjøth ${ }^{4}$ \\ ${ }^{1}$ The Asthma and Allergy Association, Roskilde Denmark \\ ${ }^{2}$ Department of Oto-Rhino-Laryngology, Medical University of Vienna, Austria \\ ${ }^{3}$ Laboratory of Aeropalynology, Faculty of Biology, Adam Mickiewicz University, Poznań, Poland \\ ${ }^{4}$ National Pollen and Aerobiology Research Unit, Institute of Science and the Environment, University of Worcester, Worcester, \\ United Kingdom \\ ${ }^{5}$ Laboratory for Palynology, Department of Biology and Ecology, Faculty of Sciences University of Novi Sad, Novi Sad, Serbia \\ ${ }^{6}$ Department of Environmental Biology, University of Rzeszów, Rzeszów, Poland \\ ${ }^{7}$ Department of Clinical and Environmental Allergology, Medical College, Jagiellonian University, Kraków, Poland
}

Sommer J, Smith M, Sikoparija B, Kasprzyk I, Myszkowska D, Grewling Ł, Skjøth C. Risk of exposure to airborne Ambrosia pollen from local and distant sources in Europe - an example from Denmark. Ann Agric Environ Med. 2015; 22(4): 625-631. doi: 10.5604/12321966.1185764

\begin{abstract}
Background. Ambrosia artemisiifolia L. is a noxious invasive alien species in Europe. It is an important aeroallergen and millions of people are exposed to its pollen.

Objective. The main aim of this study is to show that atmospheric concentrations of Ambrosia pollen recorded in Denmark can be derived from local or more distant sources.

Methods. This was achieved by using a combination of pollen measurements, air mass trajectory calculations using the HYPLIT model and mapping all known Ambrosia locations in Denmark and relating them to land cover types.

Results. The annual pollen index recorded in Copenhagen during a 15-year period varied from a few pollen grains to more than 100. Since 2005, small quantities of Ambrosia pollen has been observed in the air every year. We have demonstrated, through a combination of Lagrangian back-trajectory calculations and atmospheric pollen measurements, that pollen arrived in Denmark via long-distance transport from centres of Ambrosia infection, such as the Pannonian Plain and Ukraine. Combining observations with results from a local scale dispersion model show that it is possible that Ambrosia pollen could be derived from local sources identified within Denmark.

Conclusions. The high allergenic capacity of Ambrosia pollen means that only small amounts of pollen are relevant for allergy sufferers, and just a few plants will be sufficient to produce enough pollen to affect pollen allergy sufferers within a short distance from the source. It is necessary to adopt control measures to restrict Ambrosia numbers. Recommendations for the removal of all Ambrosia plants can effectively reduce the amount of local pollen, as long as the population of Ambrosia plants is small.
\end{abstract}

- Key words

Ragweed, HYSPLIT, land cover, invasive alien species

\section{INTRODUCTION}

Ambrosia artemisiifolia L. (ragweed) is a noxious invasive alien species in Europe [1]. The Pannonian Plain is one of the most heavily infected areas with $A$. artemisiifolia L., and is therefore one of the largest sources of Ambrosia pollen in Europe [2, 3]. Other large source areas of Ambrosia pollen include parts of northern Italy [4], France [5] and Ukraine $[6,7]$. It has been recognized that Ambrosia has spread across Europe from these major source areas during the last 10-20 years $[8,9]$. Each Ambrosia plant produces millions of pollen grains that are small $(18-22 \mu \mathrm{m})[10,11,12]$ and can be transported long-distances to areas where the source plant is scarce or not even registered, such as parts of Poland $[6,13$, $14]$, Italy $[4,15]$, the Balkans [16], and as far as Scandinavia

Address for correspondence: Carsten Ambelas Skjøth, National Pollen and Aerobiology Research Unit, Charles Darwin Building, Institute of Science and the Environment, University of Worcester, Henwick Grove, Worcester, WR2 6AJ, UK E-mail: c.skjoth@worc.ac.uk

Received: 06 February 2014; accepted: 18 November 2014
[17]. The high allergenic capacity of the ragweed pollen grains [18] means that small amounts of Ambrosia pollen can be important for allergy sufferers, although the clinical relevance of the long distance transport (LDT) of allergenic ragweed pollen remains unclear [19]. With this in mind, a recent study has quantified both Ambrosia pollen and Ambrosia pollen allergens (Amb a 1) in air samples collected in Poznań, Poland, during episodes of long-distance transport of Ambrosia pollen from the Pannonian Plain (2010-2012) [20].

The main aim of this study is to investigate the hypothesis that atmospheric concentrations of Ambrosia pollen recorded in Denmark were solely derived from distant sources. This will be achieved by: (a) quantifying atmospheric concentrations of Ambrosia pollen in Denmark (1997-2011); (b) identifying potential LDT episodes of Ambrosia pollen in Denmark by combining the results of pollen measurements and air mass trajectory calculations; (c) investigating the extent of Ambrosia invasion in Denmark by mapping all known Ambrosia locations and relating them to land cover types that are invaded; (d) through the combined use of a local 
scale dispersion model and a regional scale trajectory model we test the hypothesis that all the observed episodes of high pollen concentrations in the country are due to LDT. The alternative hypothesis is that local populations of ragweed plants in Denmark could have contributed to the observed episodes of atmospheric concentrations of Ambrosia pollen.

\section{MATERIALS AND METHOD}

Fifteen years (1997-2011) of Ambrosia pollen data were collected in Copenhagen and Viborg (Fig. 1) by volumetric spore traps of the Hirst design [21] using the standard methodology in the Danish pollen and Spore monitoring programme [22]. Daily average and bi-hourly Ambrosia pollen concentrations are expressed as pollen grains per cubic metre of air $\left(\mathrm{P} \mathrm{m}^{-3}\right)$ following the notation described by Comtois [23]. The annual sum of daily average pollen concentrations (annual pollen index) is expressed as the number of pollen grains [23].

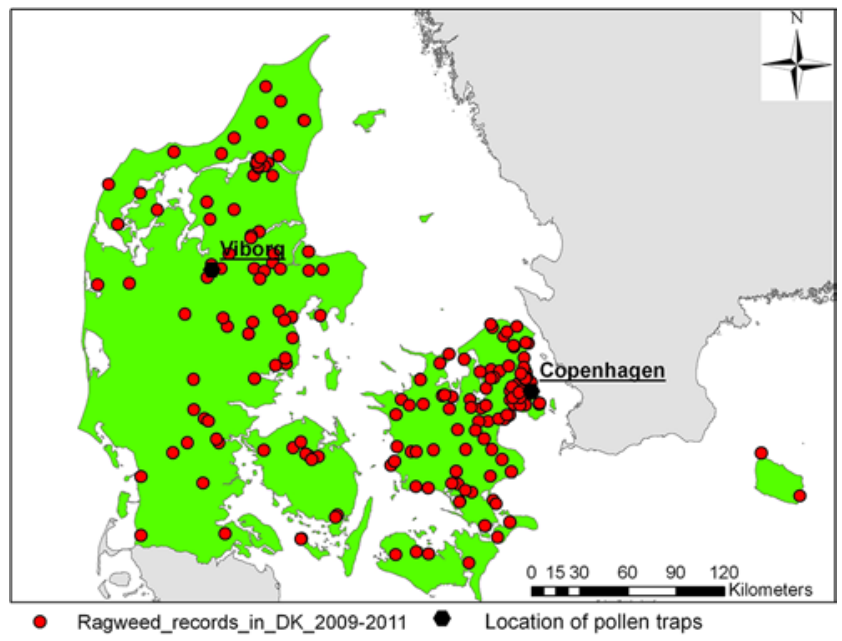

Figure 1. Location of Ambrosia artemisiifolia L. plants that have been registrated in the Danish database concerned with records of invasive species during the period 2009-2011

The overall synoptic weather situation was investigated using analysed weather maps from the UK Meteorological Office, as well as reanalysed meteorological data and meteorological observations obtained from the National Centre for Environmental Prediction (NCEP) using the methodology given in Stach et al. [14] and Kasprzyk et al. [6]. Back-trajectory calculations were conducted using the HYSPLIT model [24] following the methodology described by Stach et al. [14] that is used as an indicator of potential source areas according to and subsequently used by Smith et al. [13], Šikoparija et al. [16] and Kasprzyk et al. [6]. Input data to the HYSPLIT model is the reanalysis dataset provided by the NCEP covering the period 1948 - 2010 with a spatial resolution of 2.5 degrees and 4 grid datasets per day. Forwards calculation with a Gaussian plume model was used to estimate the concentration profile at trap height (roof level) of Ambrosia pollen grains released at the surface. Here we use the idealised approach in a similar way to that by Skjøth et al. [25], by using the OML [26] model from the DAMOS system, which is designed to combine regional scale and local scale calculations [27]. This approach allows simulations of concentration profiles at any roof-top height using either surface emissions from grasses or weeds or emissions from trees [25]. Here, we have chosen a release height of $1 \mathrm{~m}$ and the concentration profile at $20 \mathrm{~m}$. This corresponds to the typical height of the air intake on a pollen trap located on a roof-top in urban environments.

Observations of Ambrosia artemisiifolia L. plants were obtained for mapping through a data extraction from the Danish database concerned with records of invasive species (http://www.naturstyrelsen.dk/Naturbeskyttelse/ invasivearter/Indberetning/). The extraction was for the amount of Ambrosia plants, the exact geographical location of the plants and the time when the records were made during the period 2009-2011. These locations are combined with a detailed land cover dataset for the Danish area: Kort10DK [28]. Kort10DK is a vector- based dataset that contains exact information about the geographical elements in Denmark, such as individual roads, individual building, farms, lakes, streams, forests, and fields.

\section{RESULTS}

Status of Ambrosia invasion into Denmark and pollen data. According to the North European and Baltic Network on Invasive Species (NOBANIS), Ambrosia artemisiifolia L. plants were first recorded in Denmark in 1865 (http:// www.nobanis.org/speciesInfo.asp?taxaID=773). Recent observations of ragweed plants in Denmark (2009-2011) show that plants are now recorded in many parts of the country (Fig. 1), with more plants registered in the eastern parts (near Copenhagen) compared to the western parts (near Viborg). The combination of observation sites with Kort10DK data show that nearly all records are linked to residential areas. A few observations were connected with bicycle paths and churches with cemeteries. No observations could be connected with forests, lakes, streams or agricultural areas.

Since 1997, the annual pollen index (Tab. 2) in Copenhagen has ranged from 0 in 2001,2003 and 2004 to 99 Ambrosia pollen grains and 101 pollen grains in 1999 and 2002, respectively. Since 2005 Ambrosia pollen has been observed every year. The amount of Ambrosia pollen registered in the air of Viborg was lower. In Viborg, the annual pollen index was 0 for 5 years $(1997,2001,2004,2008,2010)$, and the highest annual values were 50 pollen grains (1999) and 21 pollen grains (2002). The majority of daily average Ambrosia pollen concentrations recorded during 1997-2011 were in the range of 1-2 $\mathrm{P} \mathrm{m}^{-3}(79 \%$ and $73 \%$ in Copenhagen and Viborg, respectively).

Back-trajectory analysis. Two episodes of possible LDT with daily average Ambrosia pollen concentrations higher than $20 \mathrm{P} \mathrm{m}^{-3}$ in Copenhagen and $10 \mathrm{P} \mathrm{m}^{-3}$ in Viborg are discussed below in connection with the overall weather situation and calculated air mass transport using trajectories. In addition, a third episode with Ambrosia pollen concentrations $>20 \mathrm{P} \mathrm{m}^{-3}$ has been investigated for the possibility of pollen being recorded from local sources.

Episode $5^{\text {th }}$ September 1999. No Ambrosia pollen was recorded at Copenhagen from 1 - 3 September 1999. A small number of Ambrosia pollen grains ( $3 \mathrm{P} \mathrm{m}^{-3}$ daily average) were recorded on 4 September (Tab. 1). Several fronts were located over the study area on 1 September, which were replaced by high pressure over Northern Germany ( 1025 hPa) 
Table 1. Daily average Ambrosia pollen concentration $\left(\mathrm{P} \mathrm{m}^{-3}\right)$ recorded at Copenhagen: $1^{\text {st }}$ to $8^{\text {th }}$ September $1999 ; 1^{\text {st }}$ to $8^{\text {th }}$ September $2002 ; 18^{\text {th }}$ to $25^{\text {th }}$ September 2007

\begin{tabular}{cccccc}
\hline & $\begin{array}{c}\text { Daily } \\
\text { average } \\
\text { Ambrosia } \\
\text { pollen } \\
\text { concen- } \\
\text { tration }\end{array}$ & $\begin{array}{c}\text { Daily } \\
\text { average } \\
\text { Ambrosia } \\
\text { pollen } \\
\text { concen- } \\
\text { tration }\end{array}$ & $\begin{array}{c}\text { Daily } \\
\text { average } \\
\text { Ambrosia } \\
\text { pollen } \\
\text { concen- } \\
\text { tration }\end{array}$ \\
\hline $01 / 09 / 1999$ & 0 & $01 / 09 / 2002$ & 0 & $18 / 09 / 2007$ & 0 \\
\hline $02 / 09 / 1999$ & 0 & $02 / 09 / 2002$ & 0 & $19 / 09 / 2007$ & 0 \\
\hline $03 / 09 / 1999$ & 0 & $03 / 09 / 2002$ & 0 & $20 / 09 / 2007$ & 0 \\
\hline $04 / 09 / 1999$ & 3 & $04 / 09 / 2002$ & 93 & $21 / 09 / 2007$ & 24 \\
\hline $05 / 09 / 1999$ & 54 & $05 / 09 / 2002$ & 5 & $22 / 09 / 2007$ & 0 \\
\hline $06 / 09 / 1999$ & 15 & $06 / 09 / 2002$ & 0 & $23 / 09 / 2007$ & 0 \\
\hline $07 / 09 / 1999$ & 12 & $07 / 09 / 2002$ & 0 & $24 / 09 / 2007$ & 0 \\
\hline $08 / 09 / 1999$ & 2 & $08 / 09 / 2002$ & 0 & $25 / 09 / 2007$ & 0 \\
\hline
\end{tabular}

Table 2. Annual pollen index for Ambrosia during a 15-year period at Viborg and Copenhagen (expressed as number of pollen grains)

\begin{tabular}{ccc}
\hline Year & Copenhagen & Viborg \\
\hline 1997 & 12 & 0 \\
\hline 1998 & 6 & 2 \\
\hline 1999 & 99 & 50 \\
\hline 2000 & 19 & 1 \\
\hline 2001 & 0 & 0 \\
\hline 2002 & 108 & 21 \\
\hline 2003 & 0 & 2 \\
\hline 2004 & 0 & 0 \\
\hline 2005 & 26 & 4 \\
\hline 2006 & 28 & 7 \\
\hline 2007 & 45 & 11 \\
\hline 2008 & 5 & 0 \\
\hline 2009 & 41 & 3 \\
\hline 2010 & 13 & 0 \\
\hline 2011 & 7 & 3 \\
\hline
\end{tabular}

on 2 September. During this period, the approaching air masses gradually veered from the Northwest to the East. Daily average Ambrosia pollen concentrations $>20 \mathrm{P} \mathrm{m}^{-3}$ were recorded at Copenhagen on 5 September. The highest bi-hourly Ambrosia pollen concentration was $156 \mathrm{P} \mathrm{m}^{-3}$ recorded at 12:00 on this day (Fig. 2a). This corresponded to a period when an area of high-pressure in the region of 1030-1033 hPa remained situated over European Russia, and low-pressure centres were located to the North the British Isles and Scandinavia. This resulted in air masses approaching Copenhagen from the Southeast after passing over Poland and the Ukraine. Air masses veered to the South/Southwest on 6 and 7 September (Fig. 2b), passing the Carpathians and Poland on the 6 September and arriving from a more Southwesterly direction via Germany and the Czech Republic on 7 September. At the same time, Ambrosia pollen concentrations decreased to $<20 \mathrm{P} \mathrm{m}^{-3}$ (Tab. 1).

Episode on 4 September 2002. The amount of Ambrosia pollen recorded in Copenhagen peaked sharply on 4 September 2002, resulting in a daily average Ambrosia

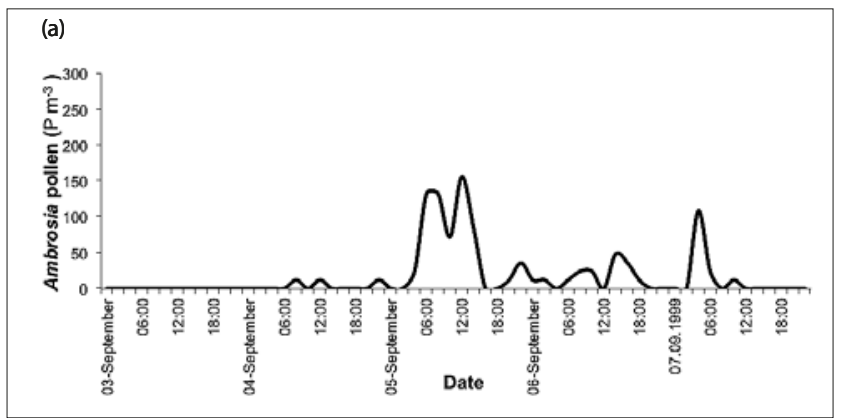

(b)

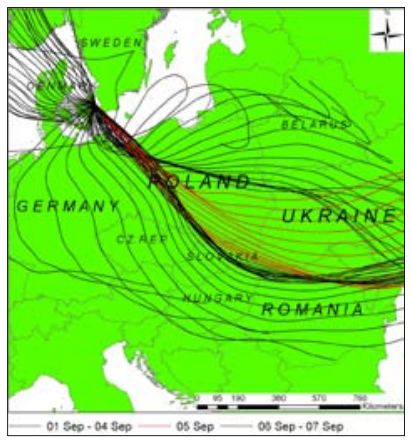

Figure 2. Bi-hourly Ambrosia pollen concentrations (a) and back-trajectories (b) calculated for Copenhagen: 1-7 September 1999

pollen concentrations of $93 \mathrm{P} \mathrm{m}^{-3}$ (Tab. 1). The synoptic situation for this period was characterised by a series of lowpressure systems $(\sim 965-986 \mathrm{hPa})$ that passed to the North of the British Isles on their passage from the North Atlantic toward Svalbard (North of mainland Scandinavia) and Arctic Russia. Corresponding high-pressure areas were located in the vicinity of Continental Europe $(\sim 1017-1032 \mathrm{hPa})$. The air masses that arrived in Copenhagen before the start of the episode approached Copenhagen from a Northwesterly direction (1 and 2 September) where they spent a considerable amount of time over the Sea (North Sea, then the Baltic Sea) before veering to the Southeast (3 September). During the episode, air masses continued to veer South and then West. Bi-hourly Ambrosia pollen concentrations peaked between 10:00 - 12:00 and again at 20:00 on 4 September, the highest bi-hourly Ambrosia pollen concentration recorded in Copenhagen on 4 was $228 \mathrm{P} \mathrm{m}^{-3}$ at 10:00. The episode carried on into 5 September, with a small peak $\left(48 \mathrm{P} \mathrm{m}^{-3}\right)$ in Ambrosia pollen recorded at 02:00 in Copenhagen (Fig. 3a) that resulted in a daily average Ambrosia pollen concentration of $5 \mathrm{P} \mathrm{m}^{-3}$ on this day (Tab. 1). Back-trajectory calculations show that air masses arriving early on 4 September came from Poland and Ukraine by mainly passing North of the Carpathians. Later on 4 and into 5 September the air masses arrived from Hungary, the Czech Republic, Slovakia and Austria via Poland and Germany (Fig. 3b). No ragweed pollen was recorded on 6 September when air masses approached from the Southwest - away from possible sources (Figs. 3a-b).

Episode on 21 September 2007. The daily average Ambrosia pollen concentration in Copenhagen was $24 \mathrm{P} \mathrm{m}^{-3}$ on 21 September 2007. No Ambrosia pollen was recorded on the days immediately before or after the episode (Tab. 1; Fig. 4a). The synoptic situation for this period was characterised by a series of low-pressure systems $(\sim 979-994 \mathrm{hPa})$ that passed to the North of the British Isles on their passage from the North Atlantic toward the northern part of Scandinavia. 


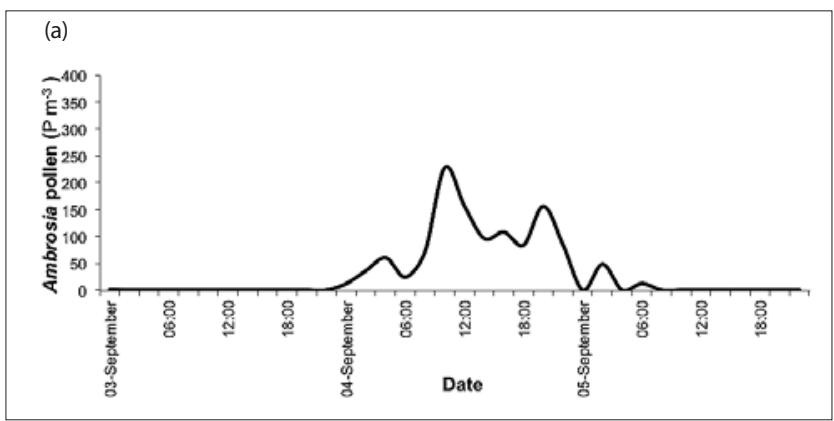

(b)

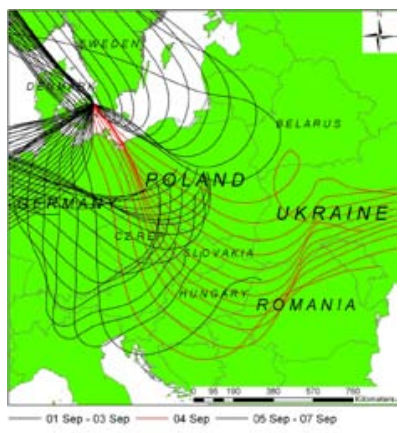

Figure 3. Bi-hourly Ambrosia pollen concentrations (a) and back-trajectories (b) calculated for Copenhagen: 1-7 September 2002

Corresponding high-pressure areas were located over Continental Europe $(\sim 1028-1030 \mathrm{hPa})$. The air masses that arrived in Copenhagen on 20 and 21 September came from the Southwest. Winds then veered to a more westerly direction on the $22^{\text {nd }}$ September. During this time, the air masses that arrived in Copenhagen spent time over parts of France, Belgium, the Netherlands, Germany, western Denmark and coastal waters (Fig. 4b). During the last hour before arriving at the pollen trap, the air masses passed over Greater Copenhagen, which is a large built up area that includes a number of records of ragweed plants (Fig. 4c). Bi-hourly Ambrosia pollen concentrations remained at zero at both Copenhagen and Viborg, apart from a period between 10:00 - 12:00 on 21 September (Fig. 4a) when a
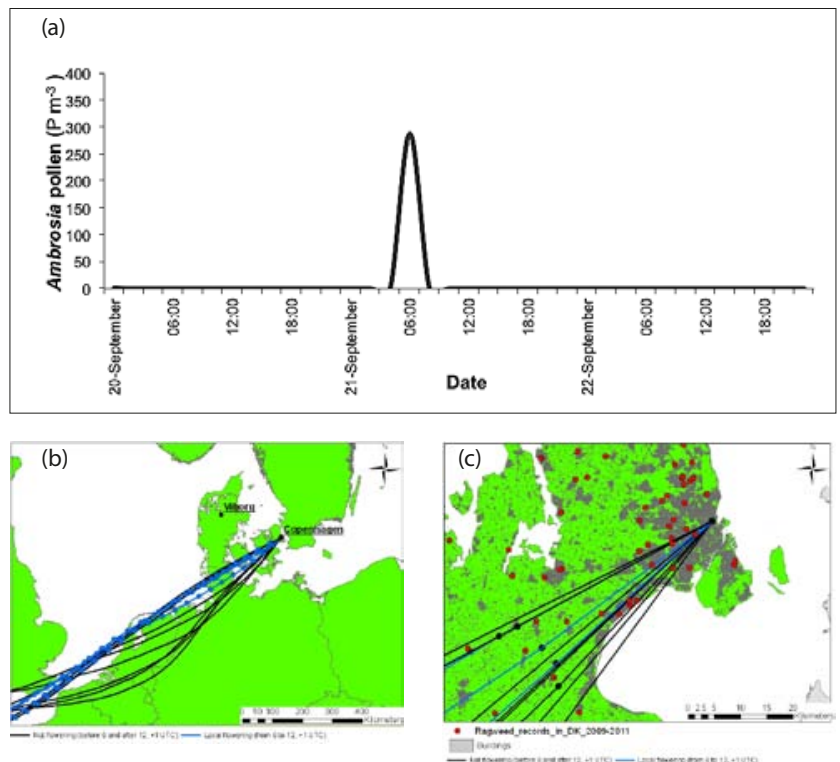

Figure 4. Bi-hourly Ambrosia pollen concentrations (a) and back-trajectories (b and c) calculated for Copenhagen: 21 September 2007

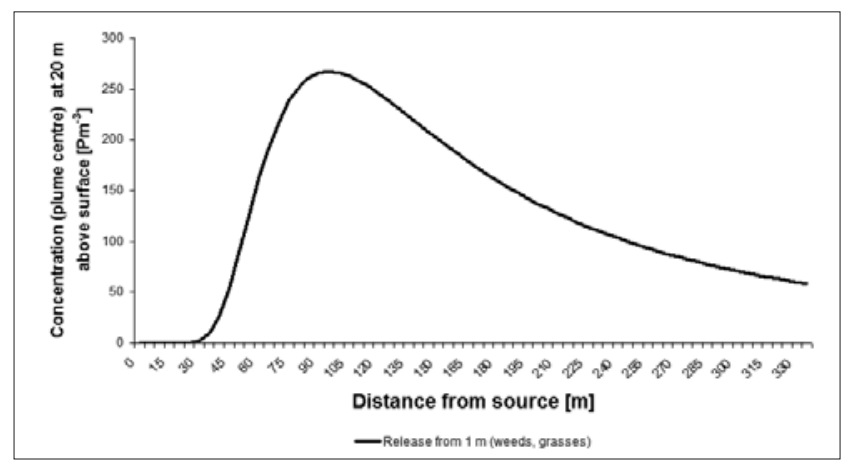

Figure 5. Ambrosia pollen concentration at $20 \mathrm{~m}$ above ground level $\left(\mathrm{P} \mathrm{m}^{-3}\right)$ following the release of $5 \times 10^{6}$ pollen grains at the surface assuming Gaussian distribution and mean weather conditions in Denmark

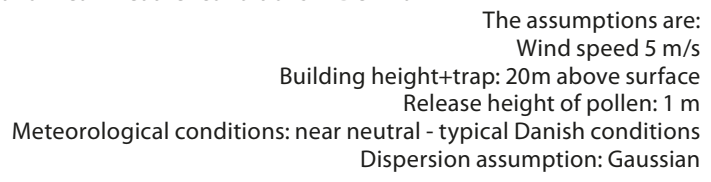

notable amount of ragweed pollen was captured by the trap in Copenhagen (bi-hourly Ambrosia pollen concentration $\left.288 \mathrm{Pm}^{-3}\right)$. No ragweed pollen was recorded in Viborg, to the West of Denmark, during the episode. Forwards calculation using the Gaussian plume model (Fig. 5) showed that a release of 5 million Ambrosia pollen grains at the surface would have caused concentrations at roof level that exceed $100 \mathrm{P} \mathrm{m}^{-3}$ between $50 \mathrm{~m}-250 \mathrm{~m}$ away from the source. In fact, concentrations would have exceeded $250 \mathrm{P} \mathrm{m}^{-3}$ at a height of $20 \mathrm{~m}$, when released at a distance in the range of $50-150 \mathrm{~m}$ from the source.

\section{DISCUSSION}

This study examines Ambrosia pollen concentrations and observations of Ambrosia artemisiifolia L. plants in Denmark. The annual Ambrosia pollen index during a 15-year period varied from a few pollen grains to more than 100 . Since 2005 , Ambrosia pollen has been observed in the air every year, although in small quantities. This could be due to pollen originating from local populations or atmospheric transport bringing ragweed pollen from distant sources.

There were 2 high magnitude Ambrosia pollen episodes ( $>20 \mathrm{P} \mathrm{m}^{-3}$ daily average) that were recorded in Copenhagen during the beginning of September in 1999 and 2002. The 2 episodes are connected to previous studies by Stach et al. [14] and Kasprzyk et al. [6]. Kasprzyk et al. [6] suggested that if the plumes of Ambrosia pollen they tracked on 5 September 1999 and 4 September 2002 did not originate from inside Poland, then it is likely that they came from Ukraine. As a result, the authors identified Ukraine as a possible new source of Ambrosia pollen for Poland, and therefore an important source area of Ambrosia pollen on the European Continent. This is supported by the present study that shows Ambrosia pollen grains were transported as far north as Scandinavia along the same path [6].

However, the Ambrosia pollen recorded on 4 and 5 September 2002 in Copenhagen travelled along 2 different paths, which coincided with 2 different peaks in bi-hourly concentrations. The first diurnal peak occurred between 10:00 - 12:00 on 4 September 2002 (Fig. 3b) and coincided with air masses that arrived from the Southeast in the direction of 
Poland and Ukraine. The trajectories continued to veer South and West during the day, and the Ambrosia pollen recorded in Copenhagen during the evening of 4 September and early morning of 5 September arrived on air masses that arrived from a more southerly direction after passing over Hungary, the Czech Republic, Slovakia, Austria, Western Poland and Eastern Germany (Fig. 3b). This identifies the Pannonian Plain as a potential source of Ambrosia pollen arriving in Copenhagen, and supports the work of Stach et al. [14] and Smith et al. [13] who showed that Ambrosia pollen arrives in Poland from the Pannonian Plain in the South. Ambrosia pollen concentrations decreased significantly on 6 September 2002 when air masses veered to the Southwest away from potential large sources of ragweed pollen.

The episode in 2007 (Figs $4 \mathrm{a}$-c) shows that ragweed pollen recorded in Copenhagen can originate from sources within Denmark, probably within the city of Copenhagen. Indeed, subsequent extraction and analysis of Kort10DK data has found that ragweed plants are within the country. Most of the Ambrosia plants were located in the East, near Copenhagen, and fewer in the West in the direction of Viborg. These plants have the potential to reach the stage of flowering. Some locations had individual plants, while other observations were of small groups. In some cases, the plants were destroyed after identification as this is the general recommendation made by the authorities.

Back-trajectories show that during the 2007 episode, the air masses arrived from areas with limited Ambrosia pollen sources, such as Danish agricultural areas, coastal areas and the North Sea. Analysis of spatial variations in allergenic pollen concentrations in Europe [29], suggests that these are unlikely to be notable sources of Ambrosia pollen. LDT is affected by dispersion that will, in general, cause episodes to last for a long period of time and cover large geographical areas. The fact that all the Ambrosia pollen grains recorded on 21 September 2007 were measured over a very short period of time (a single latitudinal transect on the microscope slide at 10:00) suggests that the episode was not the result of LDT. The LDT hypothesis is also contradicted by the fact that no Ambrosia was recorded at Viborg, to the West of Denmark, at this time.

Forwards calculation using the Gaussian plume model approach can be used to estimate concentrations at roof level at a certain distance from these potential sources [25]. On average, each ragweed plant is estimated to produce $1.19 \pm 0.14$ billion pollen grains [30]. The results of forwards calculation using the Gaussian plume model (Fig. 5) suggests that a single plant located near the pollen trap during the right environmental conditions can provide a single peak, such as the one observed in Copenhagen on 21 September 2007. The combined use of the local scale model and the regional scale model therefore rejects the hypothesis that the Ambrosia pollen in Denmark is entirely due to LDT. The alternative hypothesis - that local populations of ragweed plants in Denmark could have contributed to observed episodes of atmospheric concentrations of Ambrosia pollen, however, is supported by the use of the Gaussian plume model.

It should be noted that it is not known whether there were ragweed plants within the footprint of the pollen trap 21 September 2007. However, subsequent analysis (2009-2011) has shown that ragweed plants were present throughout the city of Copenhagen, and each of these small populations would have had the potential to create high concentrations in the vicinity of the plants. This also supports the alternative hypothesis that local populations of ragweed plants could have contributed to the observed episode. If only $1 \%$ of male flowers from a single plant released their pollen, then enough pollen would be available after half-an- hour to be transported to the pollen trap situated at a roof level [31], and the observed episode at 10:00 corresponded to the typical pollen release time [32]. This is an example of how the episode recorded in 2007 could have been caused by a small and localised population.

Examination of Ambrosia pollen data recorded in Copenhagen and Viborg since 1997 shows that most of the daily concentrations were very low, in the region of $1-2 \mathrm{Pm}^{-3}$. If it is assumed that most pollen is deposited close to the plant and atmospheric concentrations decrease with increased distance from the source [33], as shown by the Gaussian plume model, then it can be hypothesised that many of these low background concentrations recorded in Viborg and Copenhagen could also have originated from local sources within, or very close to the pollen-monitoring sites. It is therefore possible that the population of Copenhagen could be exposed to notable amounts of this potent aeroallergen at ground level from local sources, even if the amounts recorded at the trap are usually small. Furthermore, the model calculations suggest that under favourable conditions, single plants can produce and release high enough quantities of pollen to cause an allergic reaction among patients within a few hundred meters from the plant. However, the affected area is limited when the source is as small and localised as the populations recorded in Copenhagen (Fig. 1). Eradication programmes such as the Danish recommendations for ragweed (removal of all identified plants) can therefore effectively reduce the amount of local pollen, as long as the plant population is small.

In northern European countries, it is often assumed that ragweed pollen recorded at pollen-monitoring sites generally originate from distant sources. However, the presented research has shown that local plants could have released these ragweed pollen grains. If these plants are located in large urban areas, then increased temperatures due to the heat island effect can advance flowering [34], and other environmental variables, e.g. air pollution, can enhance pollen production [35, 36] and allergenicity [37]. The high allergenic capacity of ragweed means that only small amounts of ragweed pollen are relevant for allergy sufferers. In central Europe (France, Germany, Poland, Czech Republic and Slovakia), more than 100 million people live in areas with limited or notable exposure to airborne Ambrosia pollen. Moreover, a recent model that estimates future ragweed plant distribution under current climatic conditions [38] shows that an additional 180 million people in Central and Northern Europe are potentially at risk from exposure to Ambrosia pollen in the future. This includes large urban conurbations like Copenhagen, Hamburg, London and Paris, and 9 countries not currently considered to be affected by ragweed (Supplementary Figs. S1a-c; Tab. S2).

In an attempt to limit exposure to ragweed pollen, recent regulations concerning the amount of Ambrosia seeds in bird feed have been initiated by the European Union. In the autumn of 2010, the Commission amended Directive 2002/32/EC concerning foods with whole grains or seeds, with a threshold of $50 \mathrm{mg}$ of ragweed seeds per $\mathrm{kg}$. The amendment came into effect from 1 January 2012, thus 
controlling one of the mechanisms of spreading ragweed. Management, such as the immediate destruction of plants as soon as they are identified, will also help to restrict Ambrosia numbers. With a limited local population of Ambrosia, the main tool for warning the public will be mathematical models capable of simulating the atmospheric transport of Ambrosia pollen from the main European source regions. Here, the identification of both source areas and specific transport episodes, such as those in 1999 and 2002, will be important for the development and calibration of these models. Areas that contain a considerable local population must, however, also include local scale models. These models can be used to predict local concentrations, even when LDT is not present. This concept of combined LDT and local scale calculations has been shown to work for air pollutants (e.g. Geels et al. [27], Hertel et al. [39]), and is considered usable for urban scale calculations of aeroallergens once urban scale maps of aeroallergen sources have been produced [25]. By combining local and regional scale processes and explaining the near source distribution of pollen by the use of models, the current study addresses one of the major challenges in the understanding of airborne pollen transport [40].

\section{CONCLUSION}

The application of a regional scale trajectory model has shown that known centres of ragweed infection in the Pannonian Plain and Ukraine, are sources of ragweed pollen recorded in Denmark over the last 15 years. We also conclude that small populations of ragweed are present in Denmark and that these ragweed plants are associated with built-up land. It is suspected that these local populations originate from birdseed mixes contaminated with ragweed seeds. In addition, the results from a local scale Gaussian model show that small urban ragweed populations can cause elevated Ambrosia pollen concentrations in the urban zone. The calculated values correspond to the levels of ragweed pollen recorded at roof level during the examined episode. Such elevated Ambrosia pollen concentrations are likely to be present near all flowering ragweed plants. As a result, it is recommended that eradication programmes should be initiated, even for small, localised sources, because individual plants could pose a risk for allergy sufferers.

\section{Acknowledgements}

This work was partly funded by the Villum Kann Rasmussen Foundation and Danish Research Council through PostDoctoral Grants to Carsten Ambelas Skjøth, Polish National Science Centre Grant No. NN404015439, and by the Ministry of Science R. Serbia Projects No. III43002 and OI173002. The authors would like to thank the Danish Nature Agency for providing electronic access to all recorded Ambrosia habitats through the website for the registration of invasive species. The results presented here address some of the main scientific challenges described in the newly established COST Action SMARTER, specifically Task 4 under Work Group 3, concerning the construction of an integrated method that combines recorded data and coupled models for Ambrosia population development and reproduction (pollen and seeds) for management purposes of Ambrosia.

\section{REFERENCES}

1. Smith M, Cecchi L, Skjøth CA, Karrer G, Šikoparija B. Common ragweed: A threat to environmental health in Europe. Environ Int. 2013; 61(0): 115-126.

2. Rybníček O, Jäger S. Ambrosia (Ragweed) in Europe. Allergy Clin Immunol. 2001; 13(2): 60-66.

3. Skjøth CA, Smith M, Sikoparija B, Stach A, Myszkowska D, Kasprzyk I, Radisic P, Stjepanovic B, Hrga I, Apatini D, Magyar D, Páldy A, Ianovici N. A method for producing airborne pollen source inventories: An example of Ambrosia (ragweed) on the Pannonian Plain. Agric For Meteorol. 2010; 150: 1203-1210.

4. Cecchi L, Torrigiani Malaspina T, Albertini R, Zanca M, Ridolo E, Usberti I, Morabito M, Dall' Aglio P, Orlandini S. The contribution of long-distance transport to the presence of Ambrosia pollen in central northern Italy. Aerobiologia 2007; 23: 145-151.

5. Thibaudon M, Hamberger C, Guilloux L, Massot R. Ragweed pollen in France: origin, diffusion, exposure. Eur Ann Allergy Clin Immunol. 2010; 42: 209-215.

6. Kasprzyk I, Myszkowska D, Grewling Ł, Stach A, Šikoparija B, Skjøth CA, Smith M. The occurrence of Ambrosia pollen in Rzeszów, Kraków and Poznań, Poland: investigation of trends and possible transport of Ambrosia pollen from Ukraine. Int J Biometeorol. 2011; 55(4): 633-644.

7. Zemmer F, Karaca F, Ozkaragoz F. Ragweed pollen observed in Turkey: Detection of sources using back trajectory models. Sci Total Environ. 2012; 430(0): 101-108.

8. Chauvel B, Dessaint F, Cardinal-Legrand C, Bretagnolle F. The historical spread of Ambrosia artemisiifolia L. in France from herbarium records. J Biogeogr. 2006; 33: 665-673.

9. Csontos P, Vitalos M, Barina Z, Kiss L. Early distribution and spread of Ambrosia artemisiifolia in Central and Eastern Europe. Botanica Helvetica 2010; 120: 75-78.

10. Comtois P. Ragweed (Ambrosia sp.): the Phoenix of allergophytes. In: 6th International Congress on Aerobiology. Satellite Symposium Proceedings: Ragweed in Europe. Perugia, Italy: ALK Abelló. 1998.

11. Dahl A, Strandhede S-O, Wihl J-A. Ragweed - An allergy risk in Sweden? Aerobiologia 1999; 15(4): 293-297.

12. Taramaracaz P, Lambelet C, Clot B, Keimer C, Hauser C. Ragweed (Ambrosia) progression and its health risks: will Switzerland resist this invasion? Swiss Med Weekly 2005; 135: 538-548.

13. Smith M, Skjøth CA, Myszkowska D, A. U, Puc M, Stach A, Balwierz Z, Chlopek K, Piotrowska K, Kasprzyk I, Brandt J. Long-range transport of Ambrosia pollen to Poland. Agric For Meteorol. 2008; 148(10): 1402-1411.

14. Stach A, Smith M, Skjøth CA, Brandt J: Examining Ambrosia pollen episodes at Poznan (Poland) using back-trajectory analysis. Int J Biometeorol. 2007; 51: 275-286.

15. Cecchi L, Morabito M, Domeneghetti MP, Crisci A, Onorari M, Orlandini S. Long distance transport of ragweed pollen as a potential cause of allergy in central Italy. Ann Allergy Asthma Immunol. 2006; 96(1): $86-91$.

16. Šikoparija B, Smith M, Skjøth CA, Radišić P, Milkovska S, Šimić S, Brandt J. The Pannonian Plain as a source of Ambrosia pollen in the Balkans. Int J Biometeorol. 2009; 53: 263-272.

17. Šikoparija B, Skjøth CA, Alm Kübler K, Dahl A, Sommer J, Grewling Ł, Radišić P, Smith M. A mechanism for long distance transport of Ambrosia pollen from the Pannonian Plain. Agric For Meteorol. 2013; 180(0): 112-117.

18. D’Amato G, Cecchi L, Bonini S, Nunes C, Annesi-Maesano I, Behrendt H, Liccardi G, Popov T, Van Cauwenberge P. Allergenic pollen and pollen allergy in Europe. Allergy 2007; 62: 976-990.

19. Cecchi L, Testi S, Campi P, Orlandini S. Long-distance transport of ragweed pollen does not induce new sensitizations in the short term. Aerobiologia 2010; 26(4): 351-352.

20. Grewling $Ł$, Nowak M, Jenerowicz D, Szymańska A, CzarneckaOperacz M, Kostecki Ł, Bogawski P, Sikoparija B, Skjøth AC, Smith M. Atmospheric concentrations of ragweed pollen and Amb a 1 recorded in Poznań (Poland). Allergy 2013; 68(Suppl. 97): 637-707.

21. Hirst JM. An automatic volumetric spore trap. Ann Appl Biol. 1952; 39(2): 257-265.

22. Sommer J, Rasmussen A. Measurements of pollen and spores in Denmark 2009 (In Danish: Pollen- og sporemålinger i Danmark sæsonen 2009) The Astma- Allergy Association, Universitetsparken 4, 4000 Roskilde, Denmark 2009.

23. Comtois P. Statistical Analysis of Aerobiological Data. In: Mandrioli P, Comtois P, Levizzani V (Eds.) Methods in Aerobiology. Pitagora Editrice, Bologna 1998. 
24. Draxler RR, Stunder B, Rolph G, Taylor A. HYSPLIT_4 User’s Guide. 2009, NOAA Air Resources Laboratory.

25. Skjøth CA, Ørby PV, Becker T, Geels C, Schlünssen V, Sigsgaard T, Bønløkke JH, Sommer J, Søgaard P, Hertel O. Identifying urban sources as cause of elevated grass pollen concentrations using GIS and remote sensing. Biogeosciences 2013; 10: 541-554.

26. Olesen HR, Løfstrøm P, Berkowicz R, Jensen AB. An Improved dispersion model for regulatory use - the OML model. Air pollution Modelling and its Application 1992; IX: 29-38.

27. Geels C, Andersen HV, Ambelas Skjøth C, Christensen JH, Ellermann T, Løfstrøm P, Gyldenkærne S, Brandt J, Hansen KM, Frohn LM, Hertel O. Improved modelling of atmospheric ammonia over Denmark using the coupled modelling system DAMOS. Biogeosciences 2012; 9: 2625-2647.

28. National_Survey_and_Cadastre: Geometric Registration, version 3.2.0 (In Danish: Geometrisk registrering udgave 3.2.0). Kort \& Matrikelstyrelsen, Rentemestervej 8, 2400 København NV, Denmark. $178 \mathrm{pp}$.

29. Skjøth CA, Šikoparija B, Jäger S, EAN. Pollen Sources. In: Sofiev M, Bergmann K-C (Eds.) Allergenic Pollen, 9-27. Springer Netherlands 2013.

30. Fumanal B, Chauvel B, Bretagnolle F. Estimation of pollen and seed production of common ragweed in France. Ann Agric Environ Med. 2007; 14: 233-236

31. Martin MD, Chamecki M, Brush GS. Anthesis synchronization and floral morphology determine diurnal patterns of ragweed pollen dispersal. Agric For Meteorol. 2010; 150: 1307-1317.
32. Ogden EC, Hayes JV, Raynor GS. Diurnal patterns of pollen emission in Ambrosia, Phleum, Zea and Ricinus. Am J Bot. 1969; 56(1): 16-21.

33. Faegri K, Iversen J. Textbook of Pollen Analysis. John Wiley and Sons 1992.

34. Neil KL, Landrum L, Wu J. Effects of urbanization on flowering phenology in the metropolitan phoenix region of USA: Findings from herbarium records. J Arid Environ. 2010; 74(4): 440-444.

35. Ziska LH, Gerbhard DE, Frenz DA, Faulkner S, Singer BD. Cities as harbingers of climate change: Common ragweed, urbanization, and public health. J Allergy Clin Immunol. 2003; 111: 290-295.

36. Rogers C, Wayne PM, Macklin EA, Muilenberg ML, Wagner CJ, Epstein PR, Bazzaz F. Interaction of the onset of spring and elevated atmospheric $\mathrm{CO} 2$ on ragweed (Ambrosia artemisiifolia L.) pollen production. Environ Health Persp. 2006; 114(6): 865-869.

37. Singer BD, Ziska LH, Frenz DA, Gebhard DE, Straka JG. Increasing Amb a 1 content in common ragweed (Ambrosia artemisiifolia) pollen as a function of rising atmospheric $\mathrm{CO} 2$ concentration. Funct Plant Biol. 2005; 32: 667-670

38. Chapman DS, Haynes T, Beal S, Essl F, Bullock JM. Phenology predicts the native and invasive range limits of common ragweed. Global Change Biol. 2014; 20(1): 192-202.

39. Hertel O, Geels C, Frohn LM, Ellermann T, Skiøth CA, Løfstrøm P, Christensen JH, Andersen HV, Peel RG. Assessing atmospheric nitrogen deposition to natural and semi-natural ecosystems - Experience from Danish studies using the DAMOS. Atmos Environ. 2013; 66: 151-160.

40. Sofiev M, Belmonte J, Gehrig R, Izquierdo R, Smith M, Dahl A, Siljamo P. Airborne Pollen Transport. In: Sofiev M, Bergmann K-C (Eds.) Allergenic Pollen, 127-160. Springer Netherlands 2013. 